\title{
POSSIBILITIES FOR GROUND WATER USE FOR CONDITIONING OF THE FACULTY OF TECHNICS AND TECHNOLOGIES BUILDING IN YAMBOL
}

\author{
Ivan Binev \\ Faculty of Technics and Technologies, Trakia University, Bulgaria \\ Graf Ignatiev 38, 8600 Yambol, Bulgaria, e-mail: ivan.binev@trakia.uni-bg
}

\begin{abstract}
The purpose of the report is to analyze the possibilities for using heating energy for the building of the Faculty of Technics and Technology of Yambol at Trakia University of Stara Zagora, Bulgaria, provided by renewable sources. The selection of the water-water heat pump system is made after determining the heat demand for the building when applying the energy saving measures proposed in the energy efficiency audit. The possibilities for using groundwater for water supply were studied to heat the building.
\end{abstract}

Key words: Ground water, conditioning, water-water heat pump system

\section{PREFACE}

A base for study about the possibilities of energy usage for heating of the building of Faculty of Technics and Technologies of Yambol at Trakia University of Stara Zagora is adopted by the European Parliament Directive 2010/31/EC, concerning the energy performance of buildings. The Directive lays all newly constructed buildings and those liable to renovation after 2020 , to use renewable energy sources [3].

The possibility of using a water-water heat pump system involves the following tasks:

1. Selection of water-water heat pump system;

2. Exploration of the possibility of using groundwater.

By selection of variant for water-water heat pump system use, the most important feature, which has to be carefully examined before finally making a decision for equipment construction, using ground water energy source, is water flow [7]. The Faculty building is situated in the south-east part of the town of Yambol, on Graf Ignatiev street. For drinking water needs the building uses public water system. The waste water is led way in the existing sewage urban system of Yambol. The Faculty has work time 8 hours daily, five days a week, all year round ( 250 working days).

Objective: The purpose of the article is a study of possibilities for using heat-pump water-water system use of water supply aiming heating of the building of Faculty of Technics and Technologies of Trakia University of Stara Zagora.

\section{MATTERS AND METHODS}

\subsection{Matterials}

The forthcoming implementation of the energy saving recommendations proposed in the Energy Efficiency Survey of the Faculty of Technics and Technologies related to the improvement of the thermal resistance of the building envelope is a prerequisite for calculating the heat losses in the choice of a water-water heat pump system. The required heat demand after renovation of the building is $312 \mathrm{~kW}$ [1].

Hydrogeological description of the area. In the investigated area there are possibilities to obtain ground water from two underground water bodies:

1. Underground water from Early Cretaceous era cleft in Brezovo - Yambol area (code BG3G00000K2030 in Basin Directory Iztochno Belomorski (East Whitesea) Area Registry. In this area is situated the building, supposed to be conditioned. It has basic qualities [6]:

IRTIIE Vol. 6, No. 2, 2018 ISSN 1314-8788 (print), ISSN 1314-8796 (online), doi: 10.15547/artte.2018.02.013 
Area - $951 \mathrm{~km}^{2}$; no pressure type; cleft collector; feed up soil stratum; Lithological texture: tuffs, tuffits, andesite, sandstones, limestones; Average underground flow module $-0.8 \mathrm{l} / \mathrm{s} . \mathrm{km}^{2}$.

The water layer hydrogeological qualities of the investigated area are not known. The latest examination was done at the nearby Kaufland shop area. The data for filtering are obtained by the research, done in investigated tube well. The hydrogeological investigation data are: water transfusion $-\mathrm{T}=3 \mathrm{~m}^{2} / \mathrm{d}$; level transfer coefficient $-\mathrm{a}=1.106 \mathrm{~m}^{2} / \mathrm{d}$; water layer natural thickness $\mathrm{h}_{\mathrm{e}}=50 \mathrm{~m}$.

2. Underground water body Pore water in Quaternary Yambol - Elhovo - code BG3G000000Q017 in Basin Directory Iztochno Belomorski (East Whitesea) Area Registry. The investigated building is situated $150 \mathrm{~m}$ east from water body border. It has the following qualities [6]:

Area $-206 \mathrm{~km}^{2}$; no pressure type; porous collector; feed up clay sands layer; lithological texture: gravel, sand, clay; average thickness - 8-25 m; average underground flow module $-6 \mathrm{l} / \mathrm{s} . \mathrm{km}^{2}$.

The hydrogeological data of water layer from investigation of Waste water purification station in Yambol can be used for the area around the building. The data for filtering are obtained by the research, done in investigated tube well. The data of hydrogeological investigation are: water transfusion $-\mathrm{T}=1120 \mathrm{~m}^{2} / \mathrm{d}$; level transfer coefficient $-\mathrm{a}=1.103 \mathrm{~m}^{2} / \mathrm{d}$; water layer natural thickness $-h_{e}=15 \mathrm{~m}$.

\subsection{Methods}

The required water flow for the heat pump installation is calculated according to formula (1):

$$
m_{w}=\frac{3,6 Q(\varphi-1)}{c \Delta t \varphi} \cdot m^{3} / h
$$

where: $Q$ - computational heating power, kW; $\varphi$ - coefficient of heat pump transformation; c specific heat capacity of the water, $\mathrm{kJ} / \mathrm{kgK} ; \Delta \mathrm{t}$ - groundwater cooling, $\mathrm{K}(\Delta \mathrm{t}=4 \mathrm{~K})$.

To be selected site of water supply, type and number of water supply devices, it has be defined their productivity and possibility to provide necessary water quantity in different water bodies. For this purpose we take up scheme for unlimited in plan and without pressure water layer. The productivity of the water source device (one single perfect well) by quasi-stabilized regime of filtrating is calculated by the Tais's (2) equation with permissible lowering in the water body [4]:

$$
Q=\frac{\mathrm{T} \cdot \mathrm{S}_{\partial}}{0.183 \lg \frac{2.25 \mathrm{a} \cdot t_{e}}{r_{0}^{2}}}
$$

where: $Q$ is the water source device productivity, $\mathrm{m}^{3} / \mathrm{d}$; $\mathrm{T}$ is water layer transfer, $\mathrm{m}^{2} / \mathrm{d} ; \mathrm{S}_{\mathrm{d}}$ permissible lowering, $\mathrm{m}$; a - level transfer coefficient, $\mathrm{m}^{2} / \mathrm{d} ; \mathrm{r}_{0}-$ well radius, $\mathrm{m} ; \mathrm{t}_{\mathrm{e}}-$ time for exploitation forecast, $\mathrm{d}$.

The permitted lowering for water supply horizons without pressure is appointed as $60 \%$ of divergence between the water source horizon bottom depth and water static level depth, measured from the ground surface $(60 \%$ from the natural thickness). The well radius is accepted similar to most of wide-spread wells in the area: $0.15 \mathrm{~m}$ [5].

\section{RESULTS AND DISCUSSION}

The choice of the MEETING WW 90 water-water heating system was made on the basis of the determined heat losses of the building of the Facility "Technics and Technologies" - Yambol. The technical characteristics of the heat pump are presented in Table 1 [8].

IRTIIE Vol. 6, No. 2, 2018 ISSN 1314-8788 (print), ISSN 1314-8796 (online), doi: 10.15547/artte.2018.02.013 


\section{ARTTIE $Y$}

Ipplied Researthes in Technics, Technologies and Educration

Journal of the Faculty of Technics and Technologies, Trakia University

https://sites.google.com/a/trakia-uni.bg/artte/

Table 1. Technical characteristics of the heat pump system MEETING WW 90

\begin{tabular}{|l|c|c|}
\hline \multicolumn{1}{|c|}{ Parameter } & Measurement unit & Value \\
\hline Heating power & $\mathrm{kW}$ & 346 \\
\hline Power consumption & $\mathrm{kW}$ & 67,4 \\
\hline Energy transformation coefficient & & 5,12 \\
\hline Freon & ${ }^{\circ} \mathrm{C}$ & $\mathrm{R} 407 \mathrm{C}$ \\
\hline Maximum outlet water temperature & $\mathrm{number}$ & 60 \\
\hline Compressor Copeland scroll & $\mathrm{m}^{3} / \mathrm{h}$ & 3 \\
\hline Water flow from the water well & $\mathrm{m}^{3} / \mathrm{h}$ & 47,87 \\
\hline Water flow of heated water & & 59,5 \\
\hline
\end{tabular}

Water supply project. The maximum necessary water flow for the system is $53 \mathrm{~m}^{3} / \mathrm{h}$ and it depends on calculated heating power and transform coefficient of the selected heat pump system MEETING WW 90. The thermal losses in Faculty building are estimated considering the energy efficacy and the thermal insulation of building elements, suggested in the investigation [1]. For overcoming of hydraulic losses is suggested additional $10 \%: 5.3 \mathrm{~m}^{3} / \mathrm{h}$, total: $58.3 \mathrm{~m}^{3} / \mathrm{h}(16.2 \mathrm{l} / \mathrm{s})$.

The full necessary water flow for a day: $Q_{d}=58.3 \mathrm{~m}^{3} / \mathrm{h}=1400 \mathrm{~m}^{3} / 24 \mathrm{~h}$.

The full necessary water volume for a year: $Q_{a}=1400 \mathrm{~m}^{3} / 24 \mathrm{~h} .6000 \mathrm{~h}=350000 \mathrm{~m}^{3}$.

In accordance with the adopted matter of work is defined the following project water supply:

- Yearly quantity

- Average twenty-four hours volume in a year

- Average twenty-four hours flow in a year

- Maximal flow

Type and place of water supply devices selection. The number of wells in the system is determined as the wanted flow is divided to possible flow of one well [2].

The productivity of one single perfect well in underground water body BG3G00000K2030 is $0.5 \mathrm{l} / \mathrm{s}$. Water supply system: 33 wells.

The productivity of one single perfect well in underground water body BG3G000000Q017 is $10 \mathrm{l} / \mathrm{s}$. Water supply system: 2 wells.

Referring to the above calculations, it is impossible to ensure enough water quantity with only one well and water supply system has to be build.

Water supply system in the property around the examined building, situated in underground water body BG3G00000K2030 is not realistic. First - the necessary investment to build wells and pipe system is huge. Second - the coordination of so many wells work in small area will be "on interaction", i.e. their total flow will be considerable lower than the sum of nominal flows of all wells. The only possible decision to ensure of necessary water flow through underground water supply is the variant to build 2 wells in alluviums of the Tundzha River (underground water body BG3G000000Q017). The water source ground can be situated in about $150 \mathrm{~m}$ distance west from Faculty building. The disadvantages are: the change of properties rights of the places for wells as well as the necessity for about $150 \mathrm{~m}$. long water pipeline from the ground to the building. This pipeline must cross the Tundzha River bed and some land properties.

Actions, necessary to build of underground water supply. Underground water supply is subject of control permission and it is performed in accordance to clauses in Water Act and Regulation 1 / 10.10.2007 about investigation, use and protection of underground water [5]. In connection with these acts it is necessary:

1. Making a basis from geologist about underground water supply by new water supply devices tube well system. This basis is the main part of documents, required to obtain permission from Basin administration for water control "Iztochnobelomorsk" area.

2. After permission obtaining: construction of wells, including drilling, filters lay, washing, cleaning by water draw by air lift, tests of filters, chemical analysis of the water, etc. 
3. Shafts building, pumps set, water meters and necessary fittings assembling in shafts. After assembling completion control committee is set to approve of accomplished and to put it in service. 4. Construction of a water-pipe leading to the building.

5. On the stage "Basis making" it is necessary to solve the problem about take away of waste water. Waste water throw out in town sewage is difficult due to large water flow, which will overload the sewage. Due to temperature change, this water is considered as "waste" and a separate permission is necessary for water taking away. Water taking away in underground is possible, but for this purpose 3 more wells, similar to these for water source and far enough away from them, have to be build. The most realistic variant is leading water away in Tundzha River bed, even though that meets administrative difficulties.

\section{CONCLUSIONS}

The choice of the MEETING WW 90 water-heating system was made on the basis of the determined heat losses of the building of the Facility "Technics and Technologies" - Yambol. The most important feature that has been explored before the final decision to build an installation using groundwater as energy source is their flow rate.

The possibility for underground water supply aiming conditioning of the Faculty of Technics and Technologies at Trakia University - Stara Zagora is realizable. The necessary water quantity may be ensured by two "perfect" type tube wells construction (after obtaining of permission from Basin administration) at about $150 \mathrm{~m}$ west from the building - in alluvial soils of the Tundzha River. Waste water leading away is best to be done in the river bed.

\section{LITERATURE}

[1] Binev I, V. Rasheva, S. Tasheva, N. Georgieva, M. Konstantinov. (2015). Analysis of energy efficiency improvement measures at the Faculty of Technology and Technology - Yambol at Thracian University - Stara Zagora, ARTTE Applied Researches in Technics, Technologies and Education, Vol.3, No. 2, 2015, ISSN 1314-8796.

[2] Gourlevska, M. (1974). Methodological guidelines for conducting engineering geological and hydrogeological studies on construction sites and hydrogeological studies for water supply with groundwater. IPP "Energoproekt, Sofia. (in Bulgarian).

[3] European Parliament and Council Directive 2010/31 / EC on the energy performance of buildings.

[4] Ordinance No 2 of 22 March 2005 on the Design, Construction and Operation of Water Supply Systems (Promulgated in State Gazette, issue 34 of 2005, amended and supplemented, SG No. 96/2010). (in Bulgarian).

[5] Ordinance No. 1 of 10.10.2007 on Exploration, use and protection of groundwater, prom. SG No. 87 of 30.10 .2007 , in force as of 30.10.2007, amend. and supplements, nos. 102 of 23.12.2016, in force since 23.12.2016. (in Bulgarian).

[6] River Basin Management Plan in the East Aegean Region 2010-2015, East Aegean River Basin Directorate. (in Bulgarian).

[7] Pehlivanova T., Z. Zlatev, A. Dimitrova. (2016). Improvement of energy efficiency of a small household appliance. International conference of Automatics and informatics, 4-5.02.2016, ISSN: 1313-1850, Sofia, Bulgaria, pp. 53-56.

[8] https://www.researchgate.net. 